\title{
An Empirical Analysis of Export-Led Growth of Vietnam: Trade in Value Added (TiVA) Approach
}

\author{
Nguyen Viet Khoi ${ }^{1}$, Shashi Kant Chaudhary ${ }^{2}$
}

\begin{abstract}
This paper examines the long-run relationship between domestic value added exports and economic growth of Vietnam using ARDL bounds test of cointegration on annual data covering the period of 1995-2014. The bounds test establishes existence of both short-run and long-run relationship between exports and GDP of Vietnam and shows a substantial contribution of exports in the real GDP (0.73 percent for one percent changes in the domestic value added exports). The exports pattern of Vietnam portrays it following the footsteps of export-led growth model of Mexico, whereby it has turned itself into export production platforms for MNCs by suppressing the wages, rather than developing own indigenous industrial capacity. In such scenario, it seems challenging for Vietnam to sustain its export-led growth which it has achieved so far based on its cheap labour. With the rising living standards, ultimately the comparative advantages of cheap labour force would vanish in the future, which will cause a wave of assembly jobs to flow out of Vietnam. Moreover, two other low-cost countries in the region, Cambodia and Myanmar are likely to rise as close competitors of Vietnam in the low cost assembly works in the near future. By that time, in case Vietnam fails to enter into higher value added activities, it will drag itself into the 'middle income trap'. Therefore, the 'assembly strategy' shall be bonded with strategy to develop own indigenous industrial capacity, and national technological base. These will help Vietnam to upgrade its activities along value chains in forms of product upgrading, process upgrading, functional upgrading, and sectoral upgrading so that it can switch its role of 'assembling agent' to 'indigenous producer'.
\end{abstract}

Keywords: ARDL, Breakpoint Unit Root, Exports-led Growth, Value Added Export, Vietnam

\section{Introduction}

Export-led growth is a 'development strategy' that postulates that export expansion is a key factor for the economic growth of a nation. In theory, the expansion of exports can spur economic growth through several channels viz. (i) allocation of resources to the competitive sectors that results into increase in efficiency of the economy, (ii) generating employment opportunities to the unskilled labourers and improve equality, and (iii) greater inflows of FDI and technology transfers to the economy. The history of development of Germany and Japan in 1950s and 1960s; Mexico in 1970s; Asian Four Tigers (South Korea, Hong Kong, Taiwan, and Singapore), in 1980s adopting export-led growth strategies is remarkable. There are a lot of empirical works done that support the export-led economic growth hypothesis, some of these significant works are Krueger (1978), Chenery (1979), Tyler (1981), Kavoussi (1984), Balassa (1985), Chow (1987), Fosu (1990), Salvatore and Hatcher (1991) etc. In contrary to it, there are some other empirical works viz. Jung and Marshall (1985), Kwan and Cotsomitis (1990), Ahmad and Kwan (1991), Dodaro (1993), Oxley (1993), Yaghmaian (1994), and Ahmad and Harnhirum (1995) that did not find much support to the export-led economic growth hypothesis. Thus, the stories of economic success based on export-

\footnotetext{
${ }^{1}$ Professor, VNU University of Economics and Business, Hanoi, Vietnam

${ }^{2}$ Assistant Professor, British University Vietnam, Hanoi, Vietnam
} 
led strategies are limited to only a handful European and East Asian economies and hence lacks a general consensus. Nonetheless, aforementioned economies were successfully capable of maintaining sustained rapid growth until 1997,however only China has continued forging ahead at near double-digit rates since 2000, while all others have slowed down.

In the end of 1980s, Vietnam also adopted some comprehensive and radical economic reforms in sectors including foreign trade and foreign investment, to overhaul the economy in a way to adopt the export-led growth strategy. As a result, the period of first half of 1990s became the turning point in the history of 'Modern Vietnam'. During this period, Vietnam achieved remarkable economic growth, on average 8.2 percent because of these comprehensive and radical economic reforms. Apart from these reforms, some trade related developments also took place in order to open the economy, for instance, Vietnam signed trade agreement with EU in 1992; established its full diplomatic relationship with the US in 1995; and joined ASEAN in 1995. These developments would turn into milestones in the later period while talking about the 'success story' of Vietnam.

Vietnam started to realize the outcomes of these reforms and trade developments instantly. For instance, the Vietnamese economy boomed to 9.3 percent in 1996, and on an average of 7 percent over 1996-2000, despite occurrence of 'Asian Financial Crisis' in the ASEAN region during which also Vietnam stood strong with fair economic growth of about 6 percent. Along with strong economic growth, Vietnam achieved remarkable progress in socio-economic indicators as well, for example life expectancy increased from 70.5 years in 1990 to 73.3 years in 2000; GDP per capita increased to US\$ 434 in 2000 from US\$ 98 in 1990; poverty rate reduced from 60 percent in 1990 to 38.78 percent in 2002. Such significant progress in those socio-economic indicators was also reflected in improvement of the country's position in HDI values from 0.477 in 1990 to 0.576 in 2000 (UNDP, 2016). Now it is almost 30 years since the adoption of those comprehensive and radical economic reforms, the story of economic success has not stopped yet. Vietnam still stands stronger in terms of economic growth and progress in socio-economic indicators, as reflected by its quick jump from a category of 'poor country' to 'lower middle-income country' by 2011.

In recent time, a significant number of empirical studies are available on identifying the growth drivers of Vietnam's spectacular growth. These studies, in specific identify different factors as important growth drivers so far, for instance, cheap labour force, foreign direct investment (FDI), shift of labour force from agriculture to non-agriculture sectors increasing the labour productivity, strong intra-regional exports, policy reforms etc. However, in this paperwe would analyse the contribution of exports to the economic growth of Vietnam from the perspective of domestic value added exportsindicated by symbol 'DVA_EXGR' in this paper. The rest of this paper is organized as follows: section II discusses the early initiatives taken by Vietnam to enhance foreign investments and trade, which is followed by methodological framework in section III. Section III discusses the research methods, procedures and techniques used in data analysis in details. Section IV presents the empirical findings, which is followed by concluding remarks and policy discussions in section $\mathrm{V}$.

\section{2 . Early Initiatives and the Achievements}

After unification of North and South Vietnam in 1975, the country was ruled under principle of centrally planned economy until 1986. But the centrally planned principle did not seem to work well for the nation. The second and third five years plan (1976-1980 \& 1981-1986) failed to achieve their targets in terms of high economic growth rates, industrial production, agricultural production etc. due to bottlenecks such as low productivity, technological and managerial shortfalls that were present in the economy. Its foreign trade remained limited and was heavily dependent on the Soviet Union and its allies (as it was a member of 'Comecon'). In the first ten years, the average GDP growth rate remained strong (about 6 percent, most likely due to base year effect), but also remained quite volatile. The GDP growth rate 
was recorded even negative in year 1980. Likewise, the exports growth rate remained about 16 percent per year on average, but it also remained highly volatile. In the initial 9 years, 4 years' growth rate years' growth rate was recorded negative. During this period, the average share of exports in GDP remained about 15 percent.

In order to overhaul the economy, a renovation framework popularly known as 'Doi Moi' was launched in 1986. This renovation framework laid foundation of many policy reforms which resulted into transformation of Vietnamese economy from centrally planned to 'socialistoriented market economy'. The country promulgated 'Foreign Investment' law in 1987 which underwent several amendments later on to attract FDI in Vietnam. The FDI together with growth of local businesses was expected to play central role in boosting the exports of the country. However, the dissolution of Soviet-Union bloc in 1991 pushed foreign trade sector of Vietnam into trouble causing sharp fall in its exports. According to GSO (2006), Vietnam used to share about 57 percent of its total exports value with the 'Eastern Europe' alone before the dissolution of Soviet-Union bloc (1986-1990), which nosedived after 1991. Surprisingly, the GDP growth still remained 6 percent in 1991. Nonetheless, this troublous experience pushed the nation to diversify its trading partners in order to access new markets in the next few years. Some notable developments towards enhancing the foreign trade are: (i) trade agreement with the European Union in 1992, (ii) re-establishment of its relation with the US in 1995, (iii) effort to access WTO in 1995; full member of WTO in 2007; (iv) membership of ASEAN in 1995 and APEC in 1998; and (v) foreign trade relationship with 100 countries by 1995 (only 43 by 1986); 192 countries by 2000; and more than 200 economies by 2006 (GSO, 2006). Later as a member of ASEAN, Vietnam also joined other important free trade agreements (FTA) viz. ASEAN-China FTA (2002), ASEAN-Japan Comprehensive Economic Partnership (2003) and ASEAN-South Korea FTA (2005). Government of Vietnam also initiated to get into deeper international integration by signing new generation of deep preferential trade agreements (PTAs) with major country or regional trading partners such as Japan, Korea, EU and CPTPP (Comprehensive and Progressive Agreement for Trans-Pacific Partnership).

This is the outcome of all those cumulative progress that Vietnam stood with a domestic value added exports value of US\$ 94 billion in 2014, which is 17 times larger than the exports value in 1995. During this period, GDP increased from US\$ 20.7 billion in 1995 to US\$ 186.2 billion in 2014. Thus, in 2014, the share of domestic value added exports remained 50.5 percent. This achievement of Vietnam was attained in a short span of time which is remarkable. The trends of GDP and exports series and the respective growth rates are presented in figure 1.

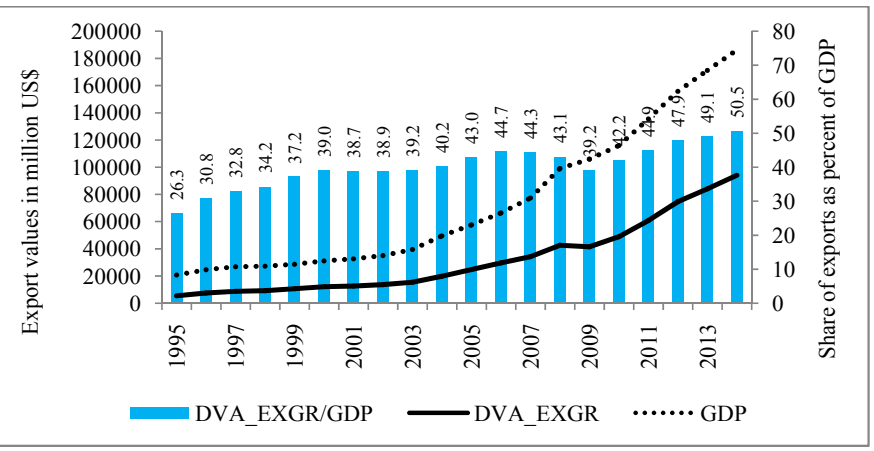

Figure Ia: Trends of Export and GDP, and their Proportion

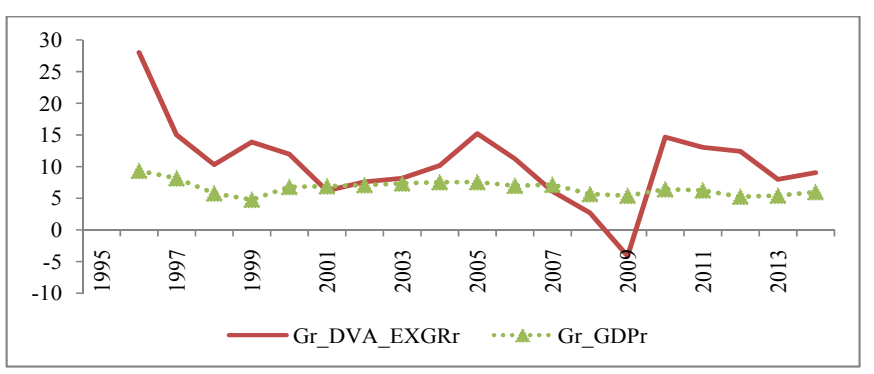

Figure Ib: Growth Rates of GDP and Export

During the study period, the domestic value added export has grown at a rate of 16.2 percent and that of the GDP at 6.6 percent. We can see that the growth rate of exports is quite volatile, while that of GDP growth rates though follow the pattern of exports, but are less volatile than growth rates of exports. The impacts of major economic shocks such as 'Asian Currency Crisis' in 1997 or 'Global Financial Crisis' in 2008' or 'Eurozone crisis' in 2010 are very clearly seen on the growth rates 
of exports. Moreover, the impact of financial crisis is severe. Aftermath crisis, the exports growth rates are negative and the GDP growth rate also fell substantially (7.1 percent in 2007 to 5.7 percent in 2008 and 5.4 percent in 2009). However, by 2010, Vietnam has made a breakthrough in terms of exports and GDP growths and clear signs of recovery can be observed. But again after 2010 until 2014, growths of exports are falling. Thus, though growth rate of GDP has shown weak sensitivity to the shocks in export growth rate, there is quite higher correlation (correlation coefficient above 0.99 ) in terms of dollar values.

\section{Data and Methodology}

The contribution of exports to the economic growth of Vietnam has been analysed through examination of existence of a long-run relationship between the domestic value added exports (DVA_EXGR) and gross domestic products (GDP), both measured in real terms. Empirically, the long-run relationship between two variables in question can be tested by using either (i) twostep Engle and Granger approach, or (ii) cointegration approach, or (iii) ARDL (autoregressive distributed lags) approach. However, the first two approaches require the underlying variables to be integrated of same order one, I(1), while the ARDL approach does not require the underlying variables to be integrated of the same order one, though none of them should be integrated of the order higher than one. This means that it is essential to test the presence of unit root and also to determine the order of integration for each of these variables if someone opts to apply the Engle and Granger approach, or cointegration approach. On the other hand, ARDL approach is applicable despite the underlying variables show a mixed order of integration, i.e. I(0) and I(1). This flexible feature of ARDL approach has made it popular in recent days as a technique to test existence of a long-run relationship.

Whilst the ARDL approach does not require testing the order of integration of variables beforehand, we have preferred to do it beforehand for two reasons- (i) at this moment,we don't know which approach would best fit to model the existence of cointegration between underlying variables. Therefore, it is better to know their order of integration beforehand, (ii) though ARDL approach seems flexible in the initial steps in ignoring the order of integration of variables, it requires at later steps to confirm that none of these variables are integrated of order 2.

At current level of literature, there are two approaches to examine the presence of unit roots in variables' series viz. (i) the unit root test that does not allow structural break (hence after we will call it 'CURT'- the conventional unit root test); and (ii) the unit root test that allows structural break (hence after we call it 'BURT'- the breakpoint unit root test). The CURT can be conducted using Augmented Dickey-Fuller (ADF), Phillips-Perron (PP), Kwiatkowski, Phillips, Schmidt, and Shin (KPSS), NgPerron test etc. However, Perron (1989) by re-examining Nelson and Plosser's work (1982) by incorporating two important structural breaks, that is, 'the great crash of 1929' and 'the oil price shock of 1973' in the underlying variables series, found that CURT test might falsely result into presence of unit root when the data are "trend stationary' with structural break(s). Surprisingly, 10 out of 13 nonstationary series were found stationary in their level forms when structural breaks were introduced in the test. Thereby Perron (1989) cautions that although use of long-span data in testing presence of a unit root allows tests with larger power in comparison to using a smaller span; however; drawback is that the long-span data may include effect of a major event, which may behave as an outlier.

In the light of Perron's caution, a researcher must be aware of the presence of outlier(s) while considering a long-span data series for testing a unit root; otherwise the use of CURT to validate the stationarity of time series might be misleading if a structural break is present in it. In this research, the underlying variables (i.e. GDP and domestic value added exports) cover a period from 1995 to 2014 for which the existing sets of literature strongly suggest possibility of structural break(s). There are at least three reasons behind this suspicion- (i) occurrence of 'Asian financial crisis' affecting ASEAN region in 
1997, (ii) occurrence of 'Global financial crisis' in 2008 affecting the US and Euro zone, which are major markets for Vietnamese exports, and (iii) Ling et al. (2013) found presence of structural breaks in 10 macroeconomic timeseries, including GDP and exports of ASEAN countries during the period of 1960-2010. They found that common structural break occurred among these ASEAN macroeconomic time series were closely associated with global economic events such as the first oil shock of 19731975 , the second oil shock of 1979-1980, the commodity crisis in 1985-1986 and the Asian financial crisis of 19971998. As Vietnam is also located in and connected with the ASEAN region, such possibility cannot be denied. However, there are some empirical works in context of Vietnam viz. Nguyen et al. (2017), Nguyen (2017), Duong (2016), Bhatt (2013), and Pham (2008) who have applied CURT approach on GDP and exports series of Vietnam to test presence of unit roots, thus overlooking the possibility of presence of structural break in GDP and exports series. All of these papers though agree that order of integration of exports series is one, I(1) in level form, they differ in determining order of integration of GDP series. Nguyen et al. (2017) and Bhat (2013) concludes it as I(1), while Nguyen (2017) confirms it to be I(0) (table 1).Upon thoughtful consideration on the facts and scenarios as discussed above, we realised that it would be better to use BURT approach to confirm the stationarity and the order of integration of the underlying variables series.

Table I: Empirical Papers Using Data Series on Exports and GDP of Vietnam

\begin{tabular}{|c|c|c|c|c|}
\hline Reference & Variable & $\begin{array}{l}\text { Cover- } \\
\text { age }\end{array}$ & $\begin{array}{l}\text { Order of } \\
\text { integration }\end{array}$ & $\begin{array}{l}\text { Meth- } \\
\text { od }\end{array}$ \\
\hline $\begin{array}{l}\text { Nguyen et } \\
\text { al. (2017) }\end{array}$ & $\begin{array}{l}\text { Net es } \\
\text { and G }\end{array}$ & $\begin{array}{l}1990- \\
2015\end{array}$ & 1) & CURT \\
\hline Sogux & $\begin{array}{l}\text { Exports and } \\
\text { GDP }\end{array}$ & $\begin{array}{l}1986- \\
2015\end{array}$ & $\begin{array}{l}\text { Export (1); } \\
\text { GDP } \rightarrow \mathrm{I}(0)\end{array}$ & CURT \\
\hline 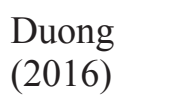 & Exp & $\begin{array}{l}1985- \\
2015\end{array}$ & $\mathrm{I}(1)$ & CURT \\
\hline $\begin{array}{l}\text { Bhatt } \\
(2013)\end{array}$ & $\begin{array}{l}\text { Ex } \\
\text { GI }\end{array}$ & $\begin{array}{l}1990- \\
2008\end{array}$ & Both $\rightarrow \mathrm{I}(1)$ & CURT \\
\hline $\begin{array}{l}\text { Pham } \\
\text { (2008) }\end{array}$ & Exports & $\begin{array}{l}1986- \\
2007\end{array}$ & $\mathrm{I}(1)$ & CURT \\
\hline
\end{tabular}

\subsection{Unit Root Test in Presence of a Single Structural Break}

Perron's work (1989) is a prominent initiative to introduce structural break in the unit root test framework. He considered three different models to test null hypothesis of a unit root against the alternative hypothesis of deterministic trend with a one-time exogeneous break in - (A) the level of the series (aka 'crash model'), (B) the slope (aka 'changing growth model'); and (C) both the level and slope. These hypotheses are parameterized as follows:

Null hypotheses:

Model (A): $\quad y_{t}=\mu+d D\left(T_{B}\right)_{t}+y_{t-1}+e_{t}$

Model (B): $\quad y_{t}=\mu_{1}+y_{t-1}+\left(\mu_{2}-\mu_{1}\right) D U_{t}+e_{t}$ Model (C): $\quad y_{t}=\mu_{1}+y_{t-1}+d D\left(T_{B}\right)_{t}+\left(\mu_{2}-\mu_{l}\right) D U_{t}+e_{t}$

Here $D U_{t}$ is 'intercept break' variable that takes the value of 0 for all dates prior to the break, and 1 thereafter (i.e. $\mathrm{DU}_{\mathrm{t}}=1$, if $\mathrm{t}>\mathrm{T}_{\mathrm{B}}, 0$ otherwise). Likewise, $\mathrm{D}\left(\mathrm{T}_{\mathrm{B}}\right) \mathrm{t}$ is 'onetime break dummy' variable which takes the value of 1 only on the break date and 0 otherwise, (i.e. $D\left(T_{B}\right)_{t}=1$, if $\mathrm{t}=\mathrm{T}_{\mathrm{B}}+1,0$ otherwise).

Alternative hypotheses:

Model (A): $\quad y_{t}=\mu_{1}+\beta t+\left(\mu_{2}-\mu_{l}\right) D U_{t}+e_{t}$

Model (B): $\quad y_{t}=\mu+\beta_{t} t+\left(\beta_{2}-\beta_{)}\right) D T_{t}^{*}+e_{t}$ Model (C): $\quad y_{t}=\mu_{l}+\beta_{t} t+\left(\mu_{2}-\mu_{l}\right) D U_{t}+\left(\beta_{2}-\beta_{l}\right) D T_{t}+e_{t}$ Here $\mathrm{DT}^{*}{ }_{\mathrm{t}}$ is 'trend break' variable which takes the value 0 for all dates prior to the break, and is a break date rebased trend for all subsequent dates (i.e.DT ${ }_{t}^{*}=t-T_{B}$ if $\mathrm{t}>\mathrm{T}_{\mathrm{B}}$ and 0 otherwise).

In these models, the difference $\left(\mu_{2}-\mu_{1}\right)$ represents the magnitude of the change in the intercept of the trend function at time $T_{B}$, and the difference $\left(\beta_{2}-\beta_{1}\right)$ represents the magnitude of the change in the slope of the trend function occurring at time $\mathrm{T}_{\mathrm{B}}$. The innovation series $\left\{\mathrm{e}_{\mathrm{t}}\right\}$ is taken to be of the $\operatorname{ARMA}(p, q)$, the orders $p$ and $q$ possibly unknown.

The null hypothesis of a unit root in the model (A) is presented in term of a dummy variable, which takes the value one at the time of break, while the alternative hypothesis allows for a one-time change in the intercept of the trend function. Likewise, the null hypothesis of the model (B) specifies that the drift parameter $\mu$ changes 
from $\mu_{1}$ to $\mu_{2}$ at time $T_{B}$. The alternative hypothesis allows a change in the slope of the trend function without any sudden change in the level at the time of the break. The model (C) allows for both effects to take place simultaneously i.e., a sudden change in the level followed by a different growth path.

For empirical purpose, Perron (1989) employed an adjusted Dickey-Fuller (ADF) type unit root testing strategy, which involve estimation of the following augmented regression equations (1) - (3) (Zivot\& Andrews, 1992):

$$
\begin{aligned}
& y_{t}=\hat{\mu}^{A}+\hat{\theta}^{A} D U_{t}+\hat{\beta}^{A} t+\hat{d}^{A} D\left(T_{B}\right)_{t}+\hat{\alpha}^{A} y_{t-1}+\sum_{j=1}^{k} \hat{c}_{j}^{A} \Delta y_{t-1}+\hat{e}_{t} \ldots \ldots(1) \\
& y_{t}=\hat{\mu}^{B}+\hat{\beta}^{B} t+\hat{\gamma}^{B} D T^{*}{ }_{t}+\hat{\alpha}^{B} y_{t-1}+\sum_{j=1}^{k} \hat{c}_{j}^{B} \Delta y_{t-1}+\hat{e}_{t} \ldots \ldots .(2) \\
& y_{t}=\hat{\mu}^{c}+\hat{\theta}^{c} D U_{t}+\hat{\beta}^{c} t+\hat{\gamma}^{c} D T^{*} t+\hat{d}^{c} D\left(T_{B}\right)_{t}+\sum_{j=1}^{k} \hat{c}_{j}{ }^{c} \Delta y_{t-1} \ldots \ldots . .(3)
\end{aligned}
$$

Perron assumd the break date as exogenously determined in these methods and known ex ante, which later ondrew a lot of criticism, Christiano (1992) being the first to point it. Later, many other studies viz. Banerjee, Lumsdaine and Stock (1992), Zivot and Andrews (1992), Perron and Vogelsang (1992), and Perron (1994) proposed procedures to address the choice of break date issue (Vogelsang and Perron, 1994). All of these four studies suggest endogenizing the choice of break date by making it data dependent. For this, two approaches have been considered, and both require estimation of a DickeyFuller type regression at all possible break dates.

The first procedure is choosing a break date that minimizes the Dickey-Fuller t-statistic across all possible regressions, and the second procedure is choosing a break date that maximizes (or minimizes, depending upon the context) a statistic which tests the significance of one or more of the coefficients on the 'trend break' dummy variables. Further, the asymptotic results are available for many combinations of trend breaks, choice of break year, and choice of AO (additive outlier) or IO (innovational outlier) models within all the four studies. For instance, Perron and Vogelsang (1992) provide results for non-trending data for both $\mathrm{AO}$ and IO models, where the break date is chosen both by minimizing the Dickey-Fuller t-statistics and by the significance of the coefficient on a mean-break dummy variable. Likewise, Zivot and Andrews (1992) provide results for trending data for the IO models, where break date is chosen by minimizing the Dickey-Fuller t-statistics (we will discuss briefly about these two models shortly in the next section). On the other hand, Banerjee et al. (1992) give results in the IO framework for the crash model and changing growth model only, where break date is chosen both by the Dickey-Fuller t-statistics and by the significance of a trend break dummy parameter.

\subsection{Discussion on Models}

Zivot and Andrews (1992) introduced an endogenous break in the Perron's (1989) models; and excluded the crash dummy $\mathrm{D}\left(\mathrm{T}_{\mathrm{B}}\right)$, thus models involves estimation of the following regression equations (4) - (6):

$$
\begin{aligned}
& y_{t}=\hat{\mu}^{A}+\hat{\theta}^{A} D U_{t}(\hat{\lambda})+\hat{\beta}^{A} t+\hat{\alpha}^{A} y_{t-1}+\sum_{j=1}^{k} \hat{c}_{j}^{A} \Delta y_{t-1}+\hat{e} t \ldots \ldots . .(4) \\
& y_{t}=\hat{\mu}^{B}+\hat{\beta}^{B} t+\hat{\gamma}^{B} D T^{*}{ }_{t}^{*}(\hat{\lambda})+\hat{\alpha}^{B} y_{t-1}+\sum_{j=1}^{k} \hat{c}_{j}^{B} \Delta y_{t-1}+\hat{e}_{t} \ldots \ldots . .(5) \\
& y_{t}=\hat{\mu}^{C}+\hat{\theta}^{c} D U_{t}(\hat{\lambda})+\hat{\beta}^{c} t+\hat{\gamma}^{c} D T^{*}(\hat{\lambda})+\hat{\alpha}^{c} y_{t-1}+\sum_{j=1}^{k} \hat{c}_{j}^{c} \Delta y_{t-1}+\hat{e}_{t}
\end{aligned}
$$

Here, $\quad D U_{t}(\lambda)=1 \quad$ if $\mathrm{t}>\mathrm{T} \lambda, 0$ otherwise.

$$
D T^{*}(\lambda)=t-T \lambda \text { if } t>T \lambda, 0 \text { otherwise. }
$$

Hats on the $\lambda$ parameters indicate estimated values of the corresponding break fraction. It is important to note that Zivot and Andrews method regards every point as a potential break-date and runs a regression for every possible break-date sequentially. The break date is selected where the t-statistic from an ADF test of unit root is at a minimum (i.e. most negative) (Waheed et al., 2006). On the other side, Perron and Vogelsang (1992) included D( $\left.\mathrm{T}_{\mathrm{B}}\right)$ in Perron's (1989) model, but excluded t, their models are given as below (7) - (9):

Innovative Outlier Model (IOM)

$y_{t}=\mu+\theta D U_{t}+\delta D\left(T_{B}\right)_{t}+\alpha y_{t-1}+\sum_{i=1}^{k} c_{i} \Delta y_{t-1}+e_{t} \cdots$

Additive Outlier Model (AOM) - Two steps

$y_{t}=\mu+\theta D U_{t}+\widetilde{y}_{t}$

$\tilde{y}_{t}=\sum_{i=0}^{k} w_{i} D\left(T_{B}\right)_{t-1}+a \widetilde{y}_{t-1}+\sum_{i=1}^{k} c_{i} \Delta \widetilde{y}_{t-1}+e_{t}$

$\tilde{y}_{t}$ in the above equations represents a detrended series $y$. Later Perron (1997) included both $\mathrm{D}\left(\mathrm{T}_{\mathrm{B}}\right)$ and $\mathrm{t}$ in his Innovational Outlier (IO1 and IO2) and Additive Outlier 
(AO) models, which are presented as below (10) - (12): IO model allowing one time change in intercept only (IO1):

$$
y_{t}=\mu_{t}+\theta D U_{t}+\beta t+\delta D\left(T_{B}\right)_{t}+\alpha y_{t-1}+\sum_{i=1}^{k} c_{i} \Delta y_{t-1}+e_{t} \ldots . .(10)
$$

IO model allowing one time change in both intercept and slope (IO2)

$$
y_{t}=\mu+\theta D U_{t}+\beta t+\gamma D T_{t}+\delta D\left(T_{B}\right)_{t}+\alpha y_{t-1}+\sum_{i=1}^{k} c_{i} \Delta y_{t-1}+e_{t} \ldots
$$

AO model allowing one time change in slope (AO)

$$
\begin{aligned}
& y_{t}=\mu+\beta t+\delta D T^{*}{ }_{t}+\tilde{y}_{t} \ldots \ldots \ldots(12) \\
& \text { Here } D T^{*}{ }_{t}=1\left(t>T_{B}\right)\left(t-T_{B}\right) \\
& y_{t}=\alpha \widetilde{y}_{t-1}+\sum_{i=1}^{\mathrm{k}} c_{i} \Delta \widetilde{y}_{t-1}+e_{t}
\end{aligned}
$$

Among bunch of these models, like any other researcher, we also faced the problem of selecting an appropriate model to determine the stationarity of a time series in presence of structural break. Results of different models in different test specification viz. (i) with intercept only, (ii) with trend only or (iii) with both intercept and trend were likely to differ, causing confusion in terms of inclusion of irrelevant information and the exclusion of relevant information. In either case, the model might be misleading. Nonetheless, in order to overcome this state of confusion Shrestha and Chowdhury's paper (2005) on 'sequential procedure' becomes an effective guideline, and thereby we have followed their sequential procedure in the unit root analysis. A flow-chart based on this paper has been presented in figure 2. Other aspects of these models have been discussed in the 'empirical results' section.

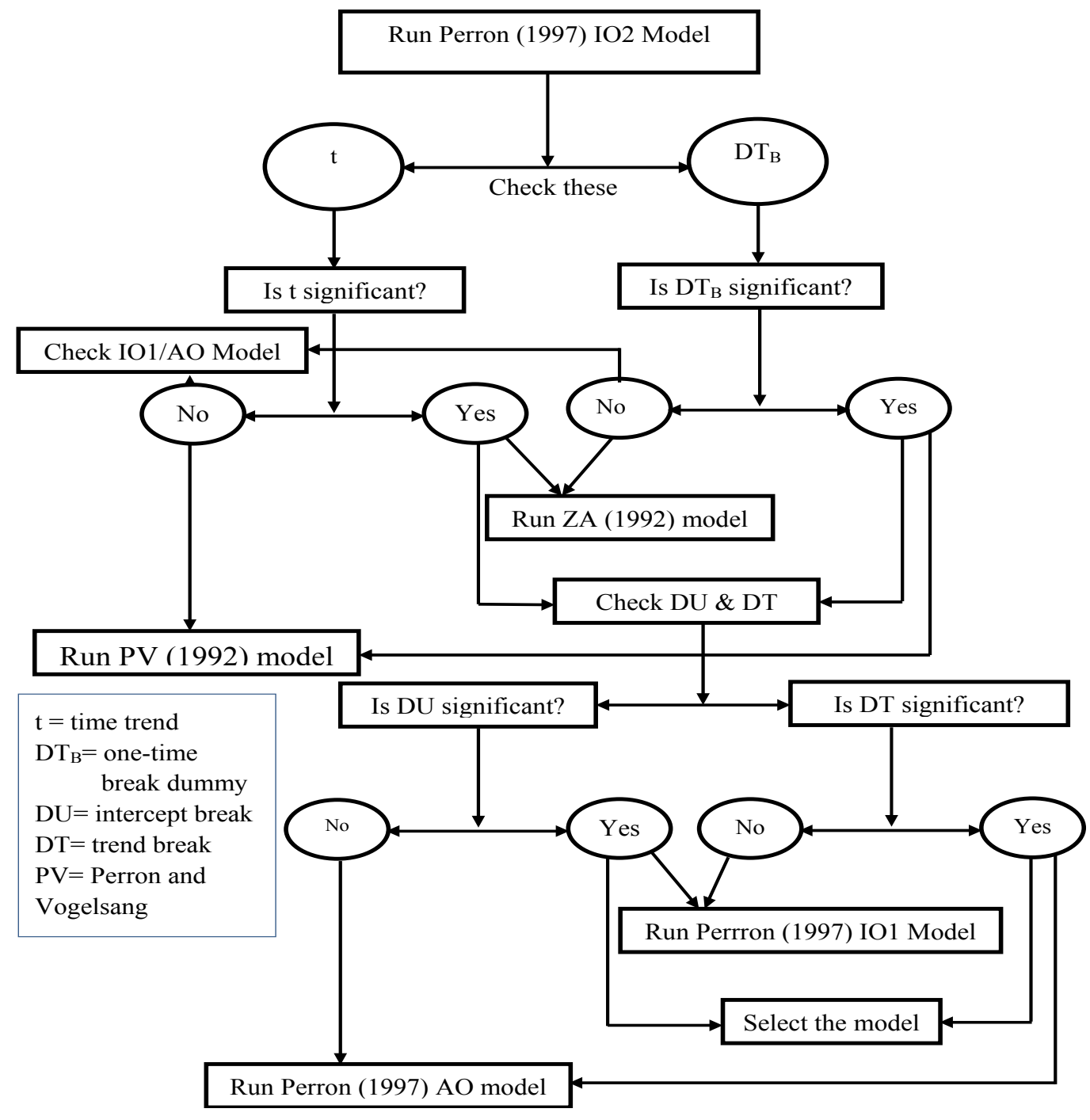

Figure II: Flow Chart for the Sequential Procedure

Source: Researchers'contribution based on sequential procedure described in Shrestha and Chowdhury's paper (2005). 
3.3 Cointegration Test

\subsubsection{Engel-Granger Approach}

The first step of Engle-Granger approach requires testing for unit roots in variable series, after which two cointegration regressions (direct and reverse) between variables are estimated using ordinary least square $(\mathrm{OLS})^{1}$ method. The second step involves testing stationarity in the error terms of the two cointegration regressions as estimated in the first step. According to Engle and Granger (1987), if the stochastic error terms are integrated of order zero, $\mathrm{I}(0)$, then $\mathrm{y}_{t}$ and $\mathrm{x}_{t}$ are said to be cointegrated. In this case, residuals from the equilibrium regression can be used to estimate the error correction model.

Hence, if variables series $\left\{\mathrm{y}_{t}\right\}$ and $\left\{\mathrm{x}_{\mathrm{t}}\right\}$ are cointegrated, the variables would have the error correction form as below:

$$
\begin{aligned}
& \Delta x_{t}=\alpha_{0}+\alpha_{x} \rho_{t-1}+\sum_{i=1}^{p} \alpha_{1 i} \Delta x_{t-1}+\sum_{i=1}^{p} \alpha_{2 i} \Delta y_{t-1}+e_{x t} \ldots . . \\
& \Delta y_{t}=\beta_{0}+\beta_{y} \rho_{t-1}+\sum_{i=1}^{p} \beta_{1 i} \Delta x_{t-1}+\sum_{i=1}^{p} \beta_{2 i} \Delta y_{t-1}+e_{y t . \ldots . .(14)}
\end{aligned}
$$

where $\Delta$ is first difference operator on variables, $\varepsilon_{\mathrm{xt}}$ and $\varepsilon_{\mathrm{yt}}$ are white noise disturbances (which may be correlated with each other), and $\alpha$ 's and $\beta$ 's are all parameters. The $\rho_{\mathrm{t}-1}$ is the error correction term (ECT) whose magnitude $\left(\alpha_{x}\right.$ or $\left.\beta_{y}\right)$ is expected to be a negative fraction between 0 and unity, and implies a 'speed of adjustment' per year of any deviation from the long run equilibrium path in order to maintain the long-run equilibrium relation between underlying variables. The independent variables are said to 'cause' the dependent variable if the error correction term (ECT), and the coefficients of the lagged independent variables (summation of $\alpha_{2 \mathrm{i}}$ in equation (13) and summation of $\beta_{1 \mathrm{i}}$ in equation (14)) are jointly significant.

\subsubsection{Johansen Test}

Johansen (1988) test of cointegration is based on the relationship between the rank of matrix and its

1 The direct and reverse cointegration regressions for two time series $Y_{t}$ and $X_{t}$ can be written as follows in log linear form:

$Y_{t}=\alpha_{0}+\alpha_{t} X_{t}+u_{1 t} \quad$ and $\quad X_{t}=\beta_{0}+\beta_{1} Y_{t}+u_{2 t}$ characteristics roots. Its generalised model can be written in form of a vector auto regression (VAR) in levels with the constant suppressed as:

$\boldsymbol{x}_{\boldsymbol{t}}=\sum_{i=1}^{k} A_{i} x_{t-i}+\boldsymbol{u}_{\boldsymbol{t}}$

For the simpler case $\mathrm{k}=1$, it is simply-

$\Delta x_{t}=\left(A_{1}-I\right) x_{t-1}+\varepsilon_{t}=\Pi x_{t-1}+\varepsilon_{t}$

where, $\mathrm{x}_{\mathrm{t}}$ and $\varepsilon_{\mathrm{t}}$ are $(\mathrm{n} \times 1)$ vectors; $\mathrm{A}_{1}=$ an $(\mathrm{n} \times \mathrm{n})$ matrix of parameters; $I=$ an $(n \times n)$ identity matrix; and $\Pi=A_{1}-I, n$ is the number of variables.

The Johansen test examines the rank of $\Pi$ matrix. If the rank $(\Pi)=0$, then the variables are not cointegrated, otherwise they are said to be cointegrated. In fact the rank of $\Pi$ provides the number of cointegrating vectors. Further, the Johansen test comprises of two tests: the maximum eigenvalue test, and the trace test. For both test statistics, the initial Johansen test is a test of the null hypothesis of no cointegration against the alternative of cointegration. These tests differ in terms of the alternative hypothesis.

\subsubsection{ARDL Bounds Test}

The basic form of an ARDL ( $p, q)$ regression model can be represented as follow:

$y_{t}=\delta_{0}+\delta_{1} t+\theta_{1} y_{t-1}+\theta_{2} y_{t-2}+\ldots+\theta_{p} y_{t-p}$

$+\beta_{I} x_{t-1}+\beta_{2} x_{t-2}+\ldots+\beta_{q} x_{t-q}+e_{t}$

Pesaran et al. (2001) reduced the basic form of ARDL to the conditional error correction form in their seminal paper which got the most attention in applied work to test for the existence of long-run relationship. Their conditional error correction form of ARDL model can be represented as follow:

$$
\Delta y_{t}=\delta_{0}+\sum_{i=1}^{p} \theta_{i} \Delta y_{t-i}+\sum_{i=0}^{q} \beta_{i} \Delta x_{t-i}+\delta_{1} t+\lambda_{1} y_{t-1}+\lambda_{2} x_{t-1}+e_{t} \ldots
$$

where $\Delta$ represents the first difference operator; $\theta$ 's are the short-run coefficients and all the terms in the summations are the short-run dynamics of the model; $\lambda$ 's are the longrun coefficients, and $\mathrm{e}$ is the error term of the equation. For testing the long-run relationship, the interest is to test that $\lambda_{1}$ and $\lambda_{2}$ are non-zero. If these are statistically equal 
to zero, it means that long-run relationship does not exist among the variables. This is done by performing 'bounds test' where one would check the significance of F-statistic for null hypothesis that 'no long-run relationship exists' (i.e. $\lambda_{1}=\lambda_{2}=0$ ). The guideline is that if value of F-statistic is greater than the upper bound (I1) critical value, it is called to be significant and one can reject the null hypothesis, otherwise cannot reject it.

Once the 'bounds test' leads to the conclusion of cointegration, the long-run relationship between variables can be estimated by the following regression equation:

$y_{t}=\alpha_{0}+\alpha_{r} x_{t}+u$

The residual series $\left\{u_{t}\right\}$ obtained from equation (19) when used in the regression equation of the short-run dynamic model would give the value of "error correction term (ECT)'. Thus, the error correction model can be represented as:

$$
\Delta y_{t}=\delta_{0}+\sum_{i=1}^{p} \theta_{i} \Delta y_{t-i}+\sum_{i=0}^{q} \beta_{i} \Delta x_{t-i}+\rho u_{t-1}+v_{t}
$$

where, $\mathrm{u}_{\mathrm{t}-1}=\left(\mathrm{y}_{\mathrm{t}-1}-{ }_{0}-{ }_{1} \mathrm{x}_{\mathrm{t}-1}\right), \alpha$ with hats represent OLS estimates of $\alpha$ 's in the long-run equation (19), and $\rho$ is the speed of adjustment.

In this study, the basic equation to examine the contribution of domestic value added exports on GDP has been formulated as below:

$\operatorname{GDPr}=\alpha_{0}+\alpha_{1}$ DVA_EXGRr $+\mathrm{u}_{\mathrm{t}}$

where GDP and DVA_EXGR are GDP and domestic value added exports of Vietnam both measured in real terms.

\section{Variables and Data}

The data of current GDP and real GDP (base year 2005) have been taken from UNCTADSTAT. Likewise, the current data on domestic value added exports has been extracted from OECD TiVA database (2016 edition). Once data were obtained, the current and constant values of GDP were used to compute the GDP deflator that has been later used to convert current exports values into the real values. For further analysis, real values of both variables have been treated in their natural log forms viz. LNGDPr as dependent variable and LNDVA EXGRr as independent variable.

\section{Empirical Analysis}

\subsection{Testing Presence of Unit Root and Structural Break}

As stated earlier we have applied Perron's (1997) model and Zivot and Andrews' (1992) (ZA for short) model to confirm the order of integration of series $\{$ LNGDPr\}, and \{LNDVA_EXGRr\}. The appropriate model has been chosen following the 'sequential procedure' as presented in section (3.2) of 'methodological framework'. In Perron's model, the break date has been chosen by minimizing the Dickey-Fuller t-statistics, and the optimal lag length was set automatic to be chosen by the software based on Schwarz information criteria (SIC). The decision on nonstationarity or stationarity of the series has been laid on the level of significance of ADF statistics in Perron's model and the ZA statistic in ZA model within 5 percent level. Estimated results are presented in Table II.

Series: Real GDP (LNGDPr)

Under Perron's IO2 model, the ADF statistic for \{LNGDPr\} in level form is not found significant at 5 percent level. So is the case in its first differenced form. Nonetheless it is significant at 10 percent level. But as the accepted level of significance is 5 percent so, we considered it insignificant. Moreover, the "time trend (t)' and 'break dummy $\left(\mathrm{DT}_{\mathrm{B}}\right)$ ' were also insignificant at 5 percent level. Therefore, following the 'sequential procedure' IO1 model was estimated next. Under Perron's IO1 model, the ADF statistic for $\{$ LNGDPr $\}$ in level form is also not found significant, but is significant in its difference form at 5 percent level. Moreover, coefficients of both 'time trend' and 'intercept' are also found significant. Therefore, LNGDPr is nonstationary in level form, integrated of order 1 or I(1). The structural break is found to exist in the series in year 2002 (Table II).

\section{Series: Real domestic value added exports (LNDVA_EXGRr)} The test statistics of IO2 model for \{LNDVA_EXGRr\} suggest that it is integrated of order (0). Time trend (t)', 'dummy break (DTB)' and 'intercept break (DU)' are found significant, while 'trend break (DT)' is 
insignificant. In such situation, the 'sequential procedure' suggests estimating IO1 model. Under IO1 model, the $\mathrm{ADF}$ statistic is significant at 1 percent level, thus confirming stationary in level form, $\mathrm{I}(0)$. Moreover, all parameters are found significant at 5 percent level. It suggests presence of structural break in the series in year 2008 (table 2). Thus the dependent variable (LNGDPr) is integrated of order one, I(1) while the independent variable (LNDVA_EXGRr) is integrated of order zero, $\mathrm{I}(0)$. This perfectly matches the necessary condition for applying ARDL (autoregressive distributed lag) approach to examine the long-run relationship between GDP and exports (i.e. order of integration of the variables shall not be of order I(2), and the dependent variable must be I(1).

\subsection{Estimating ARDL Models and Checking their Robustness}

To estimate a sound ARDL model, we tried various permutations setting the maximum lag length of 4 on both dependent variable and regressor. In the end, a maximum lags of 2 on dependent variable and 4 on regressor under specification of 'unrestricted constant and no trend'; and setting 'one time break dummy variable' on LNGDPr as fixed regressor yielded statistically valid model that is ARDL $(1,4)$. After this, we have applied BreuschGodfrey LM test to confirm that the errors of this model are not serially correlated; results of which have been presented in Table III .

The 'observed R- square' value is not found significant at 5 percent level. Therefore, the null hypothesis that 'there is no serial correlation in the model residual' cannot be rejected; it means the chosen model $\operatorname{ARDL}(1,4)$ is free from serial correlation. Hence, the outcomes of the selected ARDL models are desirable to go ahead for the next level of analysis.

Table II: Results of Breakpoint Unit Root Tests

\begin{tabular}{|c|c|c|c|c|c|c|c|c|c|}
\hline \multicolumn{10}{|c|}{ Perron (1997) Model } \\
\hline \multirow[b]{2}{*}{ Variable } & \multirow[b]{2}{*}{ Type } & \multicolumn{3}{|c|}{ Level } & \multicolumn{3}{|c|}{ First Difference } & \multirow[b]{2}{*}{$\mathbf{I}(\mathbf{p})$} & \multirow[b]{2}{*}{ Remarks } \\
\hline & & $\mathbf{T}_{\mathbf{B}}$ & $\mathbf{k}$ & ADF statistic & $\mathbf{T}_{\mathbf{B}}$ & $\mathbf{k}$ & $\begin{array}{c}\text { ADF } \\
\text { statistic }\end{array}$ & & \\
\hline LNGDPr & $\mathrm{IO} 2$ & 2004 & 0 & -3.838891 & 2003 & 1 & $-4.95469^{*}$ & $\mathrm{I}(1)$ & $\begin{array}{l}\text { Time trend }(t) \text { and break dummy } \\
\left(\mathrm{DT}_{\mathrm{B}}\right) \text { were not found significant } \\
\text { in IO2 model. }\end{array}$ \\
\hline LNGDPr & IO1 & 2002 & 0 & -3.018388 & 2002 & 1 & $-6.643501^{* * *}$ & $\mathrm{I}(1)$ & $\begin{array}{l}\text { Time trend }(t) \text { and intercept } \\
\text { break }(D U) \text { are found significant. }\end{array}$ \\
\hline $\begin{array}{l}\text { LNDVA_EX- } \\
\text { GRr }\end{array}$ & $\mathrm{IO} 2$ & 2008 & 4 & $-5.66457^{* *}$ & - & - & - & $\mathrm{I}(0)$ & $\begin{array}{l}\text { Both time trend (t) and } \\
\text { dummy break }\left(\mathrm{DT}_{\mathrm{B}}\right) \text { are found } \\
\text { significant. Intercept break (DU) } \\
\text { is also significant, but trend } \\
\text { break (DT) is insignificant. }\end{array}$ \\
\hline
\end{tabular}

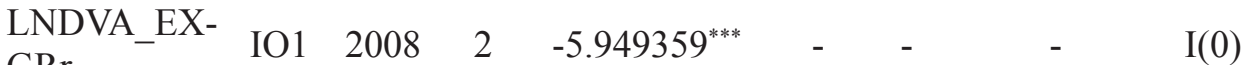

GRr

${ }^{* * *},{ }^{* *} \&{ }^{*}$ indicate significant at 1 percent, 5 percent and 10 percent level, $T_{B}=$ Break time, $k=$ lag length selected automatically by the software.

Source: Researchers'estimates.

Table III: Results of Breusch-Godfrey Serial Correlation LM Test

\begin{tabular}{cccc}
\hline F-statistic & $\mathbf{1 . 1 6 5 9 3 4}$ & Prob. F(4,4) & $\mathbf{0 . 4 4 2 7}$ \\
\hline Obs*R-squared & 8.612887 & $\begin{array}{c}\text { Prob. Chi- } \\
\text { Square(4) }\end{array}$ & 0.0715 \\
\hline
\end{tabular}

Source: Researchers'estimates.
Next, we have diagnosed the stability of the ARDL model using CUSUM test. This test plots the cumulative sum together within 5 percent critical lines. Guideline is that if the cumulative sum remains inside the area between the two critical lines, the selected model must be stable, otherwise unstable. As the CUSUM statistic for the 
chosen model lies within 5 percent critical bands (figure 3 ), means absence of any instability of the coefficients in the ARDL model.

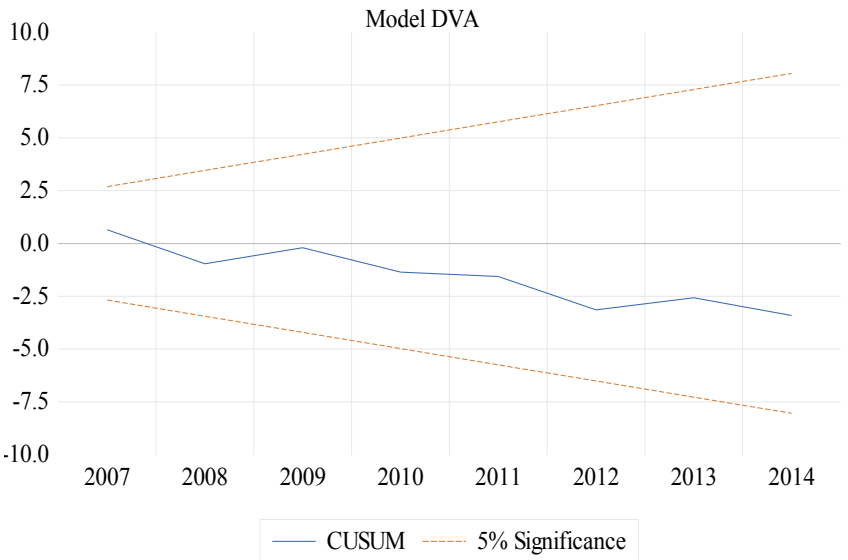

Figure III: CUSUM Test for the Chosen ARDL $(1,4)$

\subsection{Bounds Test of Cointegration and Error Correction model}

For determination of long-run relationship between GDP and exports, we have applied 'bounds test', the results of which are presented in Table IV. The F-statistic for the bounds test for the estimated ARDL $(1,4)$ model has been found bigger than the asymptotic critical value (7.84) from Pesaran et al. (2001) and finite sample critical value (9.28) from Narayan (2005) at 1 percent level. It means the null hypothesis that 'no long-run relationship exists' can be rejected at 1 percent level of significance. This validates existence of a long-run relation between GDP and exports in their level forms.

Table IV: Results of Bounds Test

\begin{tabular}{|c|c|c|c|c|c|c|c|c|}
\hline \multicolumn{3}{|c|}{$\begin{array}{c}\text { Significance Asymptotic: } n=1000 \\
\text { Pesaran et al. (2001) }\end{array}$} & \multicolumn{6}{|c|}{$\begin{array}{c}\text { Significance Finite sample: } \mathbf{n}=\mathbf{3 0} \\
\text { Narayan (2005) }\end{array}$} \\
\hline \multirow[t]{2}{*}{ F-statistic } & \multicolumn{2}{|c|}{$1 \%$} & \multicolumn{2}{|c|}{$5 \%$} & \multicolumn{2}{|c|}{$1 \%$} & \multicolumn{2}{|c|}{$5 \%$} \\
\hline & I0 & I1 & I0 & I1 & I0 & I1 & I0 & I1 \\
\hline $44.617^{* * *}$ & 6.84 & 7.84 & 4.94 & 5.73 & 8.17 & 9.28 & 5.39 & 6.35 \\
\hline
\end{tabular}

Significant at 1 percent level, $k=$ the number of independent variable in the model.

After establishing the long-run relationship between cointegration equation, the results of which have been GDP and exports, we have estimated the long-run presented in Table V.

Table V: Results of Cointegration Equation

\begin{tabular}{llccc}
\hline \multicolumn{1}{c}{ Variable } & Coefficient & Std. Error & t-Statistic & Prob. \\
\hline LNDVA_EXGRr & $0.734173^{* * *}$ & 0.008525 & 86.12359 & 0.0000 \\
\hline ECT(-1) & $-0.331045^{* * *}$ & 0.033040 & -10.01947 & 0.0000 \\
\hline
\end{tabular}

*** Significant at 1 percent level

The coefficient of LNDVA_EXGR is found positive (0.73) and highly significant, thus confirms the positive effect of gross exports on GDP. It can be interpreted as 'one percent change in domestic value added exports in real terms results into a long-run increase in real GDP of Vietnam by 0.73 percent'. This can also be viewed as the proportional change in GDP is 73 percent of the change in domestic value added exports such that when domestic value added exports rise, GDP tends to lag behind, creating disequilibrium. Such disequilibrium is corrected by 33.1 percent (which is the coefficient of 'error correction term' ECT, Table V) per year in order to maintain the long-run equilibrium relation with domestic value added exports, ceteris paribus. With this speed, the economy would take 3 years (i.e. one divided by absolute value of coefficient of ECT) to absorb the full effect of value added exports' shock on GDP.

The short-run causality in the model has been examined using Wald coefficients test, which is used to confirm the joint significance of lagged regressors on GDP. The results are reported in Table VI. To confirm the result, the estimated value of F-statistic in Wald test shall be compared with the Pesaran et al. (2001) critical value bounds. The guideline is that if F-statistic is greater than the upper bound value (i.e. I1) within 5 percent level of significance, the short-run causality runs from exports to GDP. 
Table VI: Results of Wald Test

Asymptotic critical value bounds for the F-statistic $\#, k=1$

(Case III: Unrestricted intercept and no trend)

\begin{tabular}{lcccccc}
\cline { 4 - 6 } Test Statistic & Value & df & $\mathbf{1 \%}$ Significance & \multicolumn{3}{c}{$\mathbf{5 \%}$ Significance } \\
F-statistic & $\mathbf{1 7 . 8 9 5}^{* * * *}$ & $\mathbf{( 5 , 8 )}$ & I0 & I1 & I0 & I1 \\
\hline Chi-square & 89.473 & 5 & 11.79 & 11.79 & 4.94 & 5.73 \\
\hline${ }^{* * *} \&^{* *}$ Significant at 1 percent and 5 percent level respectively. ${ }^{*}$ Pesaran & et al. $(2001, p .300), k=$ number of regressor.
\end{tabular}

Interestingly, the estimated $\mathrm{F}$ statistic is greater than the upper values at 5 percent level of significance, thus qualify the guideline. Hence, it can be concluded that causality exists between exports and GDP in the shortrun i.e. 'exports short-run causes GDP'.

\section{Conclusion}

Vietnam prioritized export expansion since its adoption of 'Doi Moi' in 1986, following the footstep of Japan, Singapore, Hong Kong, Taiwan, and South Korea. To enhance its access to foreign markets and promote exports, Vietnam also did some notable developments in the 1990s in signing bilateral and multilateral trade agreements. Visibly, since 1995 Vietnam has consistently achieved higher economic growth relying on exports, and been reaping the benefit of export-based strategy in terms of job creation, foreign reserves, and improving living standard. The ARDL bounds test of cointegration establishes existence of both short-run and long-run relationship between exports and GDP of Vietnam and shows a substantial contribution of exports in the real GDP, as much as 0.73 percent for one percent changes in the domestic value added exports. This is a fascinating number. However, a huge question is whether Vietnam can sustain this growth. To answer this question, we shall look at the growth prospective of Vietnam from two perspectives:

i. Inherent bottleneck in the export-led growth model: The overall exports pattern of Vietnam portrays it following the footsteps of export-led growth model of Mexico, whereby it has also turned itself into export production platforms for foreign multi-nationals by suppressing the wages, rather than developing own indigenous industrial capacity. Mexico model of export-led growth strategy is different from the one adopted by Germany or Japan or Asian Four Tiger countries or China. These countries' export strategies led to enhance their own industrial capacity. Nonetheless, the Mexico model has been less successful so far. Mexico has not yet recovered its strong performance of 1960-1980. Since 1980, GDP growth has been sluggish, labor productivity has been unchanged, and total factor productivity growth has been negative.

Considering the prerequisites for the Mexico model to work, it seems challenging for Vietnam to sustain its export-led growth which it has achieved so far. With the rising living standards, ultimately the comparative advantages of cheap labour force would vanish in the future, which means a wave of assembly jobs would flow out of Vietnam leaving masses of workers without jobs, creating dark days in the country. In addition, two other low-cost countries in the region, Cambodia and Myanmar are likely to rise as close competitors of Vietnam in the low cost assembly works in the near future. By that time, in case Vietnam fails to enter into higher value added tasks due to lack of adequate skills or technologies or both, it will drag itself into 'middle income trap' (a situation when a country cannot compete in low value added stages due to rising labour costs, and also cannot compete in higher value added stages due to lack of adequate skills and technologies).

ii. Changing political and macroeconomic situations: Another challenge in the existing model is to manage risks that would originate from 'supply shocks' and 'demand shocks'. Though Government of Vietnam has initiated to get into deeper international integration by signing new generation of deep 
preferential trade agreements (PTAs) with major trading partners such as Japan, Korea, EU and CPTPP apart from ASEAN-China FTA (2002), ASEANJapan Comprehensive Economic Partnership (2003), and ASEAN-South Korea FTA (2005, the changing macroeconomic situations that has developed across major trading partners of Vietnam in past few years has led to believe that the export-led growth strategy will fray for Vietnam. For instance, US consumers are debt saturated, and the US government is now more concerned about imports from outside. Europe is constrained by fiscal austerity. Japan continues to suffer from weak internal demand, and is also still hooked on export-oriented growth. That means if these macroeconomic conditions sustain the foreign demand for Vietnam's exports would weaken for sure that might have catastrophic impact on its economic growth.

Therefore, the 'assembling platform' strategy shall be bonded with strategy to develop own indigenous industrial capacity, and national technological base. These will help Vietnam to upgrade its activities along value chains in forms of (i) product upgrading, (ii) process upgrading, (iii) functional upgrading, and/or (iv) sectoral upgrading so that it can switch its role of 'assembling agent' to 'indigenous producer'. Of course, these do not seem feasible in a short term since a large proportion of Vietnamese labour forces lack adequate skills and expertise that are necessary to carry out such activities. In addition, Vietnam also lacks 'Vietnamese brand name' in international market at present time that has made it relying on foreign companies for marketing abroad. Therefore, in the meantime, government shall also prioritize involvement of domestic firms in global value chains. All of these require prompt initiatives in order to bring changes in the existing 'education and vocational training' related policies so that knowledge, skills and know-how of young generations can be enhanced. Likewise, Vietnam shall enter into more deep preferential trade agreements (PTAs) with its trading partners to be able to manage the supply and demand shocks to exports. In addition, it shall also focus on diversification of its export products and markets; and building up strong domestic demands for its products in order to sustain its economic growth.

\section{References}

Ahmad, J., \& Harnhirum, S. (1995). Unit roots and Cointegration in Estimating Causality between Exports and Economic Growth: Empirical Evidence from the ASEAN Countries. Economic Letters, 49, 329-334.

Ahmad, J., \& Kwan, A.C.C. (1991). Causality between Exports and Economic Growth. Economic Letters, 37, 243-248.

Balassa, B. (1985). Exports, Policy Choices, and Economic Growth in developing Countries After the 1973 oil Shock. Journal of Development Economics, 18, 23-35.

Banerjee, A., Lumsdaine, R.L., \& Stock, J.H. (1992). Recursive and Sequential Tests for a Unit Root: Theory and International Evidence. Journal of Business \& Economic Statistics, 10(3), 271-287.

Bhatt, P.R. (2013). Causal Relationship between Exports FDI and Income: the case of Vietnam. Applied Econometrics and International Development, 13(1), 161-176.
Chenery, H.B. (1979). Structural Change and Development Policy. New York, USA: Oxford University Press.

Chow, P.C.Y. (1987). Causality between Export Growth and Industrial Performance: Evidence from the NICs. Journal of Development Economics, 26, 55-63.

Christiano, L.J. (1992). Searching for a Break in GNP. Journal of Business \& Economic Statistics, 10(3), 237-250.

Dodaro, S. (1993). Exports and Growth:AReconsideration of causality. The Journal of Developing Areas, $27,227-244$.

Duong, T.H. (2016). The Interrelationship among Foreign Direct Investment Domestic Investment and Export in Vietnam: A Causality Analysis. Vietnam Economist Annual Meeting (VEAM). Retrieved from: http://veam.org/wp-content/ uploads/2016/08/102.-Duong-Hanh-Tien.pdf accessed on 04.05.2017. 
Fosu, A.K. (1990). Export Composition and the Impact of Export on Economic Growth of Developing Economies. Economic Letters, 34, 67-71.

General Statistics Office (GSO) (2006).20 Years of Doi Moi (1986-2005). Hanoi, Vietnam: Author.

Jung, W.S., \& Marshall, P.J. (1985). Exports, Growth and Causality in Developing Countries. Journal of Development Economics, 18, 1-12.

Kavoussi, R.M. (1984). Export Expansion and Economic Growth: Further Empirical Evidence. Journal of Development Economics, 14, 241-250.

Kawan, A.C.C, \& Cotsomitis, J. (1990). Economic growth and the Expanding Export Sector: China 1952-1985. International Economic Review, 5, $105-117$.

Krueger, A. (1978). Foreign Trade Regimes and Economic Development: Liberalization attempts and Consequences. New York, USA: National Bureau of Economic Research.

Ling, T.Y., Nor, A.H.S.M., Saud, N.A., \& Ahmad, Z. (2013). Testing for Unit Roots and Structural Breaks: Evidence from Selected ASEAN Macroeconomic Time Series. International Journal of Trade Economics and Finance, 4(4), 230-237.

Narayan, P. (2005). The Saving and Investment Nexus for China: Evidence from Cointegration Tests. Applied Economics, 37(17), 1979-1990.

Nelson, C.R., \&Plosser, C.I. (1982). Trends and Random Walks in Macroeconomic Time Series: Some Evidence and Implications.Journal of Monetary Economics, 10, 139-162.

Nguyen, T.K.N. (2017). The Long Run and Short Run Impacts of Foreign Direct Investment and Export on Economic Growth of Vietnam. Asian Economic and Financial Review, 7(5), 519-527.

Nguyen, T.N., Le, H.A., \& Mai, D.B. (2017). The Relationship between Foreign Direct Investment, Trade and Economic Growth in Vietnam. Imperial Journal of Interdisciplinary Research, 3(3), 1152-1160.

OECD stat (2017).Trade in value added (TiVA): Database (2016 edition).Paris, France: Organisation for Economic Co-operation and Development.

Oxley, L. (1993). Cointegration, Causality and Exportled growth in Portugal, 1865- 1985. Economic letters, 43, 163-166.
Perron, P. (1989). The Great Crash the Oil Price Shock and the Unit Root Hypothesis. Econometrica, 57(6), 361-1401.

Perron, P. (1994). Further Evidence on Breaking Trend Functions in Macroeconomic Variables. Research Paper, No. 9421. Montreal, Canada: Department of Economics, University de Montreal.

Perron, P. (1997). Further Evidence on Breaking Trend Functions in Macroeconomic Variables. Journal of Econometrics, 80(2), 355-385.

Perron, P., \& Vogelsang T. (1992). Nonstationarity and Level Shifts with an Application to Purchasing Power Parity. Journal of Business \& Economic Statistics, 10(3). 301-320.

Pesaran, M.H., Shin, Y., \& Smith, R.J. (2001). Bounds Testing Approaches to the Analysis of Level Relationships. Journal of Applied Econometrics, 16, 289-326.

Pham, A.M. (2008). Can Vietnam's Economic Growth be Explained by Investment or Export: A VAR Analysis.Working Paper 0815, Vietnam Development Forum. Retrieved from: http:// www.vdf.org.vn/workingpapers/vdfwp 0815 accessed on 04.05.2017.

Pilliips, P.C.B., \& Perron, P. (1988). Testing for a unit root in time series regression. Biometrika, 75(2), 335-346.

Salvatore, D., \& Hatcher, T. (1991). Inward Oriented and Outward Oriented Trade Strategies. The Journal of Development Studies, 27, 7-25.

Shrestha, M.B., \& Chowdhury, K. (2005). ARDL Modelling Approach to Testing the Financial Liberalisation Hypothesis. Working Papers, WP 05-15. Wollongong, Australia: Department of Economics, University of Wollongong.

Tyler, W.G. (1981). Growth and Export Expansion in Developing Countries: Some Empirical Evidence. Journal of Development Economics, 9, 121-130.

UNCTAD (2017). International Trade. Data Centre. Geneva, Switzerland: United Nations Conference on Trade and Development. Retrieved from: http://unctadstat.unctad.org/ wds/ReportFolders/reportFolders.aspx?sCS ChosenLang=en accessed on 04.05.2017. 
UNDP (2016). Human Development for Everyone (Briefing note for countries on the 2016 Human Development Report). New York, USA: United Nations Development Programme. Retrieved from: http:/hdr.undp.org/sites/all/themes/hdr theme/country-notes/VNM.pdf accessed on 13.05.2017.

Vogelsang, T.J., \& Perron, P. (1994). Additional Tests for a Unit Root Allowing for a Break in the Trend Function at an Unknown Time. Research Paper, No. 9422. Montreal, Canada: Department of Economics University de Montreal.

Waheed, M., Alam, T., \& Pervaiz, S. (2006). Structural Breaks and Unit Root: Evidence from Pakistani Macroeconomic Time Series.MPRA, No. 1797. Munich, Germany: Munich Personal RePEc Archive. Retrieved from: https://mpra.ub.unimuenchen.de/1797/1/MPRA_paper_1797.pdf accessed on 07.02.2017.
Yaghmaian, B. (1994). An Empirical Investigation of Exports, Development, and Growth in Developing Countries: Challenging the Neoclassical Theory of Export- Led Growth. World Development, 22, 1977-1995.

Zivot, E., \& Andrews, K. (1992). Further Evidence on the Great Crash, the Oil Price Shock and the Unit Root Hypothesis. Journal of Business and Economic Statistics, 10 (10), 251-70. 